\title{
CEREBROSPINAL FLUID FINDINGS AFTER TREATMENT OF EARLY SYPHILIS WITH PENICILLIN*
}

\author{
BY \\ W. L. FERNANDO \\ V.D. Clinic, Colombo, Ceylon
}

It has been the practice at the Central VD Clinic, Colombo, to examine the cerebrospinal fluid (CSF) as a test of cure not less than 2 years after treatment for early syphilis.

A total of 151 CSF examinations were performed between September, 1963, and August, 1964, in male patients who had been treated for primary or secondary syphilis. The examination was made within 1 hour of lumbar puncture. There were 25 cases of sero-negative primary, 90 cases of seropositive primary, and 36 cases of secondary stage syphilis.

The interval (average 3.05 years) between treatment and lumbar puncture was as follows:

\begin{tabular}{c|c|c|c|c|c|c|c|c|c}
\hline $\begin{array}{r}\text { No. of } \\
\text { Years }\end{array}$ & 2 & 3 & 4 & 5 & 6 & 7 & 8 & 9 & $\begin{array}{c}10 \text { and } \\
\text { Over }\end{array}$ \\
\hline $\begin{array}{r}\text { No. of } \\
\text { Cases }\end{array}$ & 82 & 38 & 9 & 8 & 5 & 2 & 3 & - & 4 \\
\hline
\end{tabular}

\section{Method}

Penicillin was used in the form of PAM, Benzathine penicillin, or Benapen (benethamine penicillin).

PAM was given to 101 patients in a dose of 600,000 units daily for ten injections to a total of 6 million units, but ten of these patients defaulted before completing the last one or two injections. Benzathine penicillin was given to 34 patients with primary syphilis $(1 \cdot 2$ m.u. twiceweekly for 1 week; total 2.4 m.u.) and to nine patients with secondary syphilis $(1 \cdot 2 \mathrm{~m}$.u. twice-weekly for 2 weeks; total 4.8 m.u.). Benapen was given to seven patients $(600,000$ units every other day for five injections; total of 3 m.u.).

The patients were followed up monthly for 1 year and quarterly thereafter if the blood tests were negative. The VDRL was positive at the time of the lumbar puncture in ten cases, of which two were possibly sero-relapses (there was no history of re-infection), four had had one or more attacks of gonorrhoea during the follow-up period, and two were re-infected with syphilis. None of these ten

\footnotetext{
* Received for publication March 16th, 1965
}

patients had any abnormality in the CSF. The remaining 141 (93 per cent.) of the 151 cases were sero-negative at the time of lumbar puncture.

\section{Results of CSF Examinations}

Cells.-More than three cells per c.mm. were taken as abnormal. Four cases showed more than three cells per c.mm.; of these two had four cells, one had seven cells, and one had thirteen cells per c.mm.

One patient with a normal cell count, who had increased protein $(60 \mathrm{mg}$. per cent. and a slightly abnormal Lange curve), on re-testing 3 months later had seven cells per c.mm. and a normal Lange curve although the protein remained at $60 \mathrm{mg}$. per cent. as before. A subsequent examination 2 months later showed normal cells, a slightly altered Lange curve, and protein $40 \mathrm{mg}$. per cent. This patient has remained under observation and shows no evidence of neurosyphilis.

Protein.-A level above $30 \mathrm{mg}$. per cent. was taken as abnormal. Only one patient (the same as mentioned under Cells) had a protein count of $60 \mathrm{mg}$. per cent., and this was found to be $40 \mathrm{mg}$. per cent. 2 months later.

Lange Curve.-Only one patient (as mentioned under Cells) had a slightly abnormal Lange curve of 0011000000 ; on re-examination 3 months later it was normal, and after a further 2 months it showed a similar minor change.

VDRL.-The examination of the CSF was negative in all 151 cases.

The CSF was thus normal in all cases except that in which there were varying changes in the cells, Lange curve, and protein. This patient had been treated for sero-positive primary syphilis in 1961 with 4.8 m.u. Benzathine penicillin; he subsequently had gonorrhoea for which he was given adequate penicillin treatment on four occasions during the follow-up period before the lumbar puncture. 


\section{Discussion}

Thomas (1949) stated that the cerebrospinal fluid reflected the activity of the syphilitic inflammatory process in the central nervous system (CNS) with amazing accuracy, and King (1964) noted that it was generally agreed that treatment with penicillin in the early stages of syphilis was remarkably effective in preventing involvement of the CNS and in effecting a cure when the CNS was already involved.

Bauer, Price, and Cutler (1952) detected CSF abnormalities before treatment in about 5 per cent. of cases of primary and secondary syphilis (more than ten cells and a positive serological test). In the present series only two patients had a cell count of more than four cells per c.mm.

Cutler, Bauer, Price, and Schwimmer (1954), who tested the CSF in 561 normal subjects, 503 patients with primary syphilis, and 560 patients with secondary syphilis, found that a few normal subjects had a cell count higher than ten per c.mm. and that more showed a protein count of more than $40 \mathrm{mg}$. per cent. In the present series, none of the patients with increased cells had any abnormality in the other constituents of the CSF. Only one patient had increased protein $(60 \mathrm{mg}$. per cent.) but 2 months later the count was $40 \mathrm{mg}$. per cent. Only one patient (as mentioned earlier) had a slightly abnormal Lange curve.

The results of CSF examination after treatment for early syphilis have been reported by various workers. King (1959) suggested follow-up after penicillin treatment of early syphilis for at least 2 years and with at least one CSF examination at one year or more after treatment. Chargin, Sobel, Vandow, and Rosenthal (1958), following up 27 cases of primary syphilis and 23 cases of secondary syphilis for 5 to 11 years after penicillin treatment, found one ( 2 per cent.) with asymptomatic neurosyphilis (the type of penicillin and the duration of administration were not stated). Perdrup (1960) found that the CSF was normal at least one year after treatment in all of 78 cases of early syphilis in which lumbar puncture was carried out. Hellerström and Skog (1962) found that the CSF was normal at least one year after penicillin treatment for early syphilis in all of 51 patients in whom lumbar puncture was performed. Jefferiss and Willcox (1963) found only one abnormal CSF in 81 CSF examinations made 9 months or more after penicillin treatment for early syphilis, and this one abnormal finding was considered to be dubious. Jefferiss (1963) stated that it was generally agreed that one abnormal result in the various CSF tests without support from the others was suspect, and he did not favour CSF examination as a routine test after adequate treatment of early syphilis, but King (1964) suggested that a patient should be regarded as cured after treatment for early syphilis only if a clinical recovery was maintained during at least 2 years of observation, with absence of infectivity to others and persistently negative tests for syphilis in the blood and CSF.

\section{Summary}

The cerebrospinal fluid findings in 151 cases of early syphilis at least 2 (average 3.05 ) years after treatment with penicillin are presented. In 150 the CSF findings were considered to be normal. In one case, the findings varied on repetition on two subsequent occasions and were considered as being definitely not due to neurosyphilis.

The results of penicillin treatment for primary and secondary syphilis appear to be excellent.

The question of abandoning the CSF examination as a routine test of cure in adequately treated early syphilis needs to be considered.

I wish to acknowledge my thanks to Mr A. L. Dassanayake of the Central VD Laboratory for helping me with the CSF examinations.

\section{REFERENCES}

Bauer, T. J., Price, E. V., and Cutler, J. C. (1952). Amer. J. Syph., 36, 309.

Chargin, L., Sobel, N., Vandow, J., and Rosenthal, T. (1958). Acta derm.-venereol. (Stockh.), 38, 168.

Cutler, J. C., Bauer, T. J., Price, E. V., and Schwimmer, B. H. (1954). Amer. J. Syph., 38, 447.

Hellerström, S., and Skog, E. (1962). Acta derm.-venereol. (Stockh.), 42, 179.

Jefferiss, F. J. G. (1963). Brit. J. vener. Dis., 39, 139.

- and Willcox, R. R. (1963). Ibid., 39, 143.

King A. J. (1959). Brit. med. J., 1, 355.

(1964). "Recent Advances in Venereology", pp. 47, 80 , and 147. Churchill, London.

Perdrup, A. (1960). Acta derm.-venereol. (Stockh.), 40, 340.

Thomas, E. W. (1949). "Syphilis: its Course and Management", p. 21. Macmillan, New York.

Étude du liquide céphalo-rachidien après traitement de la syphilis précoce par la pénicilline.

\section{RÉSUMÉ}

On présente une étude du liquide céphalo-rachidien dans 151 cas de syphilis précoce traités par la pénicilline pendant au moins 2 ans (la moyenne étant 3,05 ans). Dans 150 cas le liquide apparut normal. Dans un cas les résultats changèrent lors de 2 examens successifs, et on considéra qu'ils n'étaient certainement pas dus à une neurosyphilis.

Les résultats du traitement à la pénicilline en cas de syphilis primaire et secondaire semblent excellents.

On peut se demander si l'examen systématique du liquide céphalo-rachidien est nécessaire, pour assurer la guérison d'une syphilis précoce bien traitée. 